\title{
Regulation of Expression of Novel Mandelate Dehydrogenases in Mutants of Acinetobacter calcoaceticus
}

\author{
By CELIA A. HILLS $\dagger$ AND CHARLES A. FEWSON* \\ Department of Biochemistry, University of Glasgow, Glasgow G12 8QQ, U.K.
}

(Received 25 October 1982; revised 14 January 1983)

\begin{abstract}
Wild-type strains of Acinetobacter calcoaceticus able to grow on only L(+)- or $\mathrm{D}(-)$-mandelate gave rise to mutants that could grow on the other isomer of mandelate. Each mutant contained an additional mandelate dehydrogenase which was not expressed in the parent strain. The novel enzymes were shown to be controlled co-ordinately with the pre-existing enzymes for the conversion of mandelate into benzoate when induced with phenylglyoxylate, gratuitously induced with thiophenoxyacetate, subjected to anti-induction by 2-phenylpropionate or catabolite-repressed by succinate. Mutants which had been selected on the basis of possession of a constitutive phenylglyoxylate decarboxylase also constitutively expressed both the original and the novel mandelate dehydrogenases.
\end{abstract}

\section{INTRODUCTION}

Acinetobacter calcoaceticus wild-type strain NCIB 8250 can grow on L( + )-mandelate but not on $\mathrm{D}(-)$-mandelate and has only an $\mathrm{L}(+)$-mandelate dehydrogenase; however, we isolated mutants that can also grow on $\mathrm{D}(-)$-mandelate and possess a novel $\mathrm{D}(-)$-mandelate dehydrogenase (Hills \& Fewson, 1983). Conversely, wild-type strain EBF $65 / 65$ has only a D(-)mandelate dehydrogenase but gives rise to mutants containing an $\mathrm{L}(+)$-mandelate dehydrogenase (Hills \& Fewson, 1983). Both strains can also grow on benzyl alcohol. The converging metabolic pathways for the oxidation of mandelate and benzyl alcohol are shown in Fig. 1.

The properties of the novel mandelate dehydrogenases proved to be very similar to those of the original dehydrogenases (Hills \& Fewson, 1983) and the question arose as to how these new enzymes are regulated. In the present paper we describe how two independent approaches indicate that the novel enzymes are regulated co-ordinately with the pre-existing enzymes that convert mandelate into benzoate. Some of these results have been presented in a preliminary form (Hills \& Fewson, 1979).

\section{METHODS}

Bacteria. Acinetobacter calcoaceticus wild-type strain NCIB 8250 was obtained from the National Collection of Industrial Bacteria, Aberdeen, Scotland. Wild-type strain EBF $65 / 65$ and mutant C48 were kindly provided by Dr A. Vivian, Thames Polytechnic, London.

The isolation and properties of the mutants used in this work are summarized in Fig. 2. Some of the strains have been deposited in the National Collection of Industrial Bacteria and these have been listed by Hills \& Fewson (1983). Mutant C4248 was previously designated 61c (Towner, 1978).

Growth of bacteria and preparation of extracts. General methods for the maintenance of cultures and for the growth, harvesting and storage of bacteria have been summarized by Hills \& Fewson (1983). 'Basal medium' contained $2 \mathrm{~g} \mathrm{KH}_{2} \mathrm{PO}_{4}$ and $1 \mathrm{~g}\left(\mathrm{NH}_{4}\right)_{2} \mathrm{SO}_{4}$ in 1 litre of glass-distilled water and was adjusted to $\mathrm{pH} 7.0$ with $\mathrm{NaOH}$. 'Salts medium' was prepared by adding $20 \mathrm{ml} 2 \%(\mathrm{w} / \mathrm{v}) \mathrm{MgSO}_{4} \cdot 7 \mathrm{H}_{2} \mathrm{O}$ per litre of basal medium.

In experiments where enzyme activities were to be measured, $0.1 \mathrm{ml}$ samples of stock cultures were inoculated into Oxoid CMl nutrient broth $\left(100 \mathrm{ml}\right.$ in $500 \mathrm{ml}$ Erlenmeyer flasks) and grown at $23^{\circ} \mathrm{C}$ without shaking for $48 \mathrm{~h}$ in the case of strain NCIB 8250 and its mutants or for $40 \mathrm{~h}$ in the case of EBF 65/65 and its mutants. These cultures

$\dagger$ Present address: Institute of Cancer Research, Clifton Avenue, Belmont, Surrey SM2 5PX, U.K. 


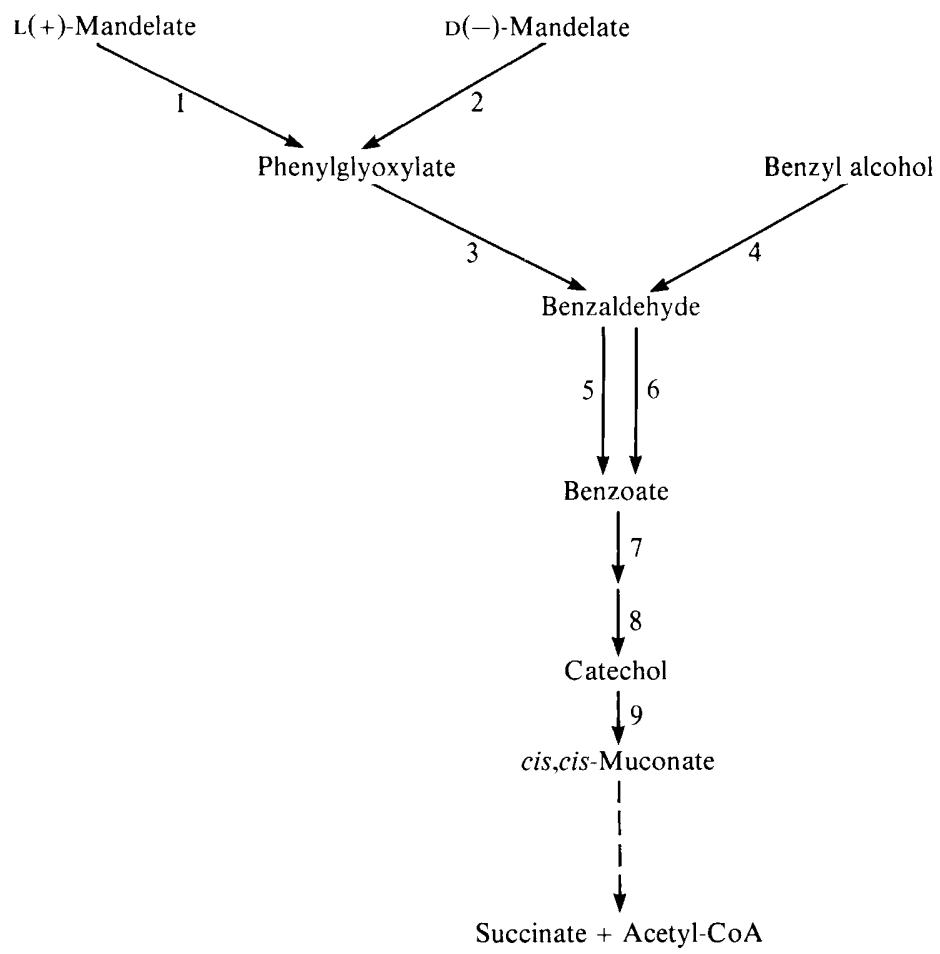

Fig. 1. Metabolism of mandelate and benzyl alcohol by $A$. calcoaceticus. In wild-type strain NCIB 8250 $\mathrm{L}(+)$-mandelate dehydrogenase (1), phenylglyoxylate (benzoylformate) decarboxylase (3; EC 4.1.1.7) and benzaldehyde dehydrogenase I (5) are co-ordinately induced by phenylglyoxylate and gratuitously induced by thiophenoxyacetate (Livingstone \& Fewson, 1972). In wild-type strain EBF 65/65 D(-)mandelate dehydrogenase (2), phenylglyoxylate decarboxylase (3) and benzaldehyde dehydrogenase I (5) are co-ordinately induced by phenylglyoxylate and thiophenoxyacetate (results in this paper and unpublished results of $\mathrm{A}$. Scott and C. A. Fewson). In both wild-type strains benzyl alcohol dehydrogenase (4) and benzaldehyde dehydrogenase II (6) are co-ordinately induced by benzyl alcohol or benzaldehyde (Livingstone et al., 1972; unpublished results of A. Scott and C. A. Fewson) and are repressed whenever phenylglyoxylate decarboxylase is present (Beggs \& Fewson, 1977). Benzoate oxygenase (7) and cyclohexadienediolcarboxylate dehydrogenase (8) appear to form a separate regulon (Reiner, 1971), as does catechol-1,2-oxygenase (9; EC 1.13.11.1) which is induced by cis,cis-muconate (Stanier \& Ornston, 1973).

were used as inocula $(25 \%, \mathrm{v} / \mathrm{v})$ for $5 \mathrm{mM}-\mathrm{L}$-glutamate/salts media containing appropriate supplements as described in the Tables. All media were prepared so that the concentrations were correct after inoculation. The cultures $\left(400 \mathrm{ml}\right.$ in 1 litre flasks) were grown at $23^{\circ} \mathrm{C}$ with vigorous stirring and aeration (Harvey et al., 1968; Beggs \& Fewson, 1977). Samples were taken at intervals for measurement of turbidity and the bacteria were harvested when the $A_{500}$ reached 0.5 to 0.7 ; this corresponded to approximately two generations and took between 2 and $5 \mathrm{~h}$ depending on the strain and the medium used. The bacteria were harvested by centrifuging at $6000 \mathrm{~g}$ for $20 \mathrm{~min}$ at $4{ }^{\circ} \mathrm{C}$, washed by resuspension in ice-cold basal medium and then centrifuging at $12000 \mathrm{~g}$ for $30 \mathrm{~min}$ at $4{ }^{\circ} \mathrm{C}$ and finally stored at $-18^{\circ} \mathrm{C}$.

Extracts were prepared by suspending bacteria in $0 \cdot 1 \mathrm{M}-\mathrm{KH}_{2} \mathrm{PO}_{4} / \mathrm{K}_{2} \mathrm{HPO}_{4}$ buffer, pH $7 \cdot 5$, so that a 20 -fold dilution had an $A_{500}$ of 0.25 . The suspensions were then disrupted by ultrasonic treatment as described by Livingstone et al. (1972) except that the current was $3 \mathrm{~A}$. Intact bacteria and debris were removed by centrifuging at $12000 \mathrm{~g}$ for $30 \mathrm{~min}$ at $4{ }^{\circ} \mathrm{C}$. The supernatant 'extracts' were then assayed immediately or stored at $-18^{\circ} \mathrm{C}$.

Isolation of constitutive mutants. Mutants constitutive for phenylglyoxylate decarboxylase were isolated by a modification of the procedure of Fewson et al. (1978). Samples $(0 \cdot 1 \mathrm{ml})$ of $24 \mathrm{~h}$ nutrient broth cultures of the parent strains were spread on plates containing $2 \mathrm{~mm}$-2-phenylpropionate $+2 \mathrm{~mm}$-phenylglyoxylate/salts medium and $1.5 \%(\mathrm{w} / \mathrm{v})$ Oxoid no. 1 agar. A few crystals of $N$-methyl- $N^{\prime}$-nitro- $N$-nitrosoguanidine were placed in the centre of some of the plates. Presumptive mutant colonies appearing during $10 \mathrm{~d}$ incubation at $30^{\circ} \mathrm{C}$ were transferred to nutrient broth $(10 \mathrm{ml})$, grown for $24 \mathrm{~h}$ at $30^{\circ} \mathrm{C}$ and then cloned by streaking on plates of 2-phenylpropionate + 


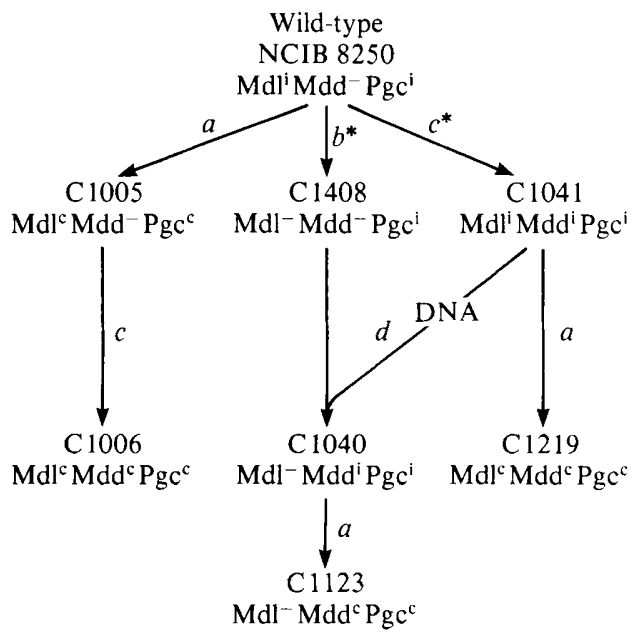

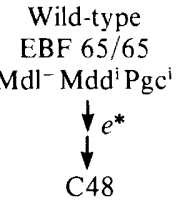

$\mathrm{Mdl}^{-} \mathrm{Mdd}^{\mathrm{i}} \mathrm{Pgc}$ ile-1 met-1

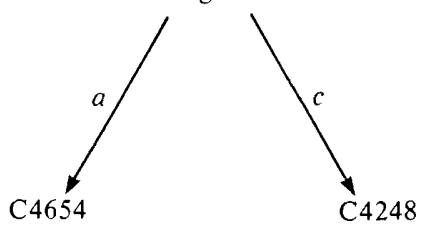

$\mathrm{MdI}^{-} \mathrm{Mdd}^{\mathrm{C}} \mathrm{Pgc}^{\mathrm{c}}$ ile-1 met-1 Mdi Mddi Pgcile-1 met-1

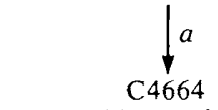

$\mathrm{Mdl}^{\mathrm{c}} \mathrm{Mdd}^{\mathrm{c}} \mathrm{Pgc}^{\mathrm{c}}$ ile-1 met-I

Fig. 2. Genealogy of mutants of $A$. calcoaceticus. (a) Isolation of strains with constitutive phenylglyoxylate decarboxylase activity by selection for growth on $2 \mathrm{mM}$-2-phenylpropionate (as antiinducer) +2 mM-phenylglyoxylate/salts medium (see Methods; Fewson et al., 1978); $(b)$ isolation of blocked mutant able to grow on phenylglyoxylate but not on mandelate (Livingstone \& Fewson, 1972); (c) isolation of strains able to grow on $\mathrm{L}(+)$ - or $\mathrm{D}(-)$-mandelate (Hills \& Fewson, 1983); (d) transformation and selection for ability to grow on $\mathrm{D}(-)$ - but not $\mathrm{L}(+)$-mandelate (Ahlquist et al., 1980; Hills \& Fewson, 1983); (e) double auxotroph isolated by Towner \& Vivian (1976). A few of the steps $\left({ }^{*}\right)$ involved mutagenesis, usually with $N$-methyl- $N^{\prime}$-nitro- $N$-nitrosoguanidine, as described in the appropriate references, but the others were all spontaneous mutants. Phenotypes: Mdl, L(+)mandelate dehydrogenase; Mdd, D(-)-mandelate dehydrogenase; Pgc, phenylglyoxylate decarboxylase; the superscripts -, $\mathrm{i}$ and $\mathrm{c}$ denote no enzyme, inducible activity, and constitutive activity respectively.

phenylglyoxylate medium. Only about one-fifth of the colonies proved to have constitutive enzyme activities; the rest had presumably gained some other property that allowed them to grow in the presence of 2-phenylpropionate. To eliminate these unwanted strains, we made use of the observation that mutants possessing a constitutive phenylglyoxylate decarboxylase cannot grow readily on benzyl alcohol (Beggs \& Fewson, 1977). We therefore made serial dilutions of the isolates and placed drops $\left(10^{-4}\right.$ and $10^{-5}$ dilutions in basal medium) on to plates of nutrient agar and on to plates of $5 \mathrm{~mm}$-benzyl alcohol/salts agar. Strains that showed very faint or no growth after incubation for $48 \mathrm{~h}$ on benzyl alcohol were checked for the constitutive synthesis of phenylglyoxylate decarboxylase; inducible strains (including the wild-types, which were always included as controls) had formed large colonies by this time.

Measurements of enzyme activities. The following enzyme activities were measured using extracts: $D(-)$ - and $\mathrm{L}(+)$-mandelate dehydrogenases by the method of Hills \& Fewson (1983), benzaldehyde dehydrogenase by the method of Beggs \& Fewson (1977) and catechol-1,2-oxygenase by the method of Hegeman (1966). Phenylglyoxylate decarboxylase and benzyl alcohol dehydrogenase activities were measured using bacteria that had been treated with toluene, as described by Beggs \& Fewson (1977) and Beggs et al. (1976) respectively. Toluene-treated bacteria were used because of the greater speed and convenience of this method and because smaller amounts of bacteria were required; unfortunatelv we have not yet developed a procedure for measuring $\mathrm{D}(-)$-mandelate dehydrogenase in toluene-treated bacteria, and whilst $\mathrm{L}(+)$-mandelate dehydrogenase can be measured in such cells (Beggs et al., 1976), it seemed prudent to measure the activities of both mandelate dehydrogenases in the same preparation. All these assays were done in triplicate. Results are given as means and the replicates rarely showed a spread of more than $5 \%$.

There is no convenient assay procedure for benzoate oxygenase so rates of $\mathrm{O}_{2}$ uptake by intact bacteria were measured using Clark-type $\mathrm{O}_{2}$ electrodes maintained at $27^{\circ} \mathrm{C}$ (Hills \& Fewson, 1983). The reaction mixture (final volume $3.0 \mathrm{ml}$ ) contained $67 \mathrm{mM}-\mathrm{KH}_{2} \mathrm{PO}_{4} / \mathrm{K}_{2} \mathrm{HPO}_{4}$ buffer, $\mathrm{pH} 7.0$, and bacteria equivalent to an $A_{500}$ of 1 . Endogenous rates of respiration were measured for about $5 \mathrm{~min}$ and then benzoate was added $(0 \cdot 1 \mathrm{ml}$ of a $15 \mathrm{~mm}$ solution adjusted to $\mathrm{pH} \mathrm{7.0)}$ and $\mathrm{O}_{2}$ uptake followed for a further $5 \mathrm{~min}$. Duplicate measurements were made in each case.

Materials and analytical methods. These were as listed by Hills \& Fewson (1983). 


\section{RESULTS AND DISCUSSION}

\section{Occurrence of mutants with novel mandelate dehydrogenases}

We made approximate estimates of the frequency of spontaneous occurrence of mutants able to grow on the second isomer of mandelate. Wild-type NCIB 8250 gave rise to colonies able to grow on $\mathrm{D}(-)$-mandelate at a frequency of about 1 in $3 \times 10^{10}$. The frequency for strain C1408 (a mutant of NCIB 8250 lacking L(+)-mandelate dehydrogenase; Fig. 2) was very similar (approximately 1 in $2 \times 10^{10}$ ); its frequency of reversion to an active $\mathrm{L}(+)$-mandelate dehydrogenase was rather lower (about 1 in $9 \times 10^{10}$ ). Strain $\mathrm{C} 48$ showed a considerably higher frequency of occurrence of mutants able to grow on $\mathrm{L}(+)$-mandelate (about 1 in $3 \times 10^{8}$ ). Mutagenesis with $N$-methyl- $N^{\prime}$-nitro- $N$-nitrosoguanidine increased these frequencies. In the original experiments a trace amount of phenylglyoxylate $(0.25 \mathrm{~mm})$ was included in the mandelate plates used for selection in order to ensure that the mandelate enzymes were induced; however, omission of phenylglyoxylate did not seem to affect the frequency at which mutants were detected. After the discovery that $\mathrm{D}(-)$-mandelate dehydrogenase is very heat-labile (Hills $\&$ Fewson, 1983), some experiments were done at $23^{\circ} \mathrm{C}$ rather than at $30^{\circ} \mathrm{C}$ but, again, this had little effect on the frequencies.

A few of the mutants (e.g. C1219) are rather susceptible to lysis, particularly when grown in defined media at higher temperatures (e.g. $30^{\circ} \mathrm{C}$ ) with vigorous agitation.

Eleven mutants (including $\mathrm{C} 1041$ and $\mathrm{C} 4248$ ) were examined in some detail. The $\mathrm{D}(-)$ mandelate dehydrogenase appeared to have identical properties in every strain and was almost completely inhibited by $10 \mu \mathrm{M}$ - $p$-chloromercuribenzoate and lost about $85 \%$ of its activity after incubation at $30^{\circ} \mathrm{C}$ for $4 \mathrm{~h}$, whereas in every strain the $\mathrm{L}(+)$-mandelate dehydrogenase activity was virtually unaffected by these treatments (see also Hills \& Fewson, 1983).

\section{Regulation of the inducible novel mandelate dehydrogenases}

The novel enzymes, $\mathrm{D}(-)$-mandelate dehydrogenase in mutant $\mathrm{C} 1041$ and $\mathrm{L}(+)$-mandelate dehydrogenase in $\mathrm{C} 4248$, were inducible. Like the original enzymes, they were synthesized in the presence of $\mathrm{D}(-)$ - or $\mathrm{L}(+)$-mandelate or phenylglyoxylate as well as in the presence of the gratuitous inducer thiophenoxyacetate (Table 1). All the enzymes were subject to almost complete anti-induction by 2-phenylpropionate and to co-incident catabolite repression by succinate (Table 1).

In a series of experiments of the type described in Table 1, using mutants C1041 and C4248, correlation coefficients were calculated on the assumption that a linear relationship existed between the activities of the pairs of enzymes $\mathrm{L}(+)$-mandelate dehydrogenase and $\mathrm{D}(-)$ mandelate dehydrogenase, $\mathrm{L}(+)$-mandelate dehydrogenase and phenylglyoxylate decarboxylase, and $\mathrm{D}(-)$-mandelate dehydrogenase and phenylglyoxylate decarboxylase. The lowest correlation coefficient was 0.86 and most values were between 0.95 and $\mathbf{0 . 9 8}$.

\section{Mutants with constitutive enzyme activities}

The aim of these experiments was to test whether in mutants which synthesized the original mandelate enzymes constitutively the novel mandelate dehydrogenases were also constitutive or whether they were still inducible. It should be stressed that the isolation procedure was based solely on the selective advantage of having a constitutive phenylglyoxylate decarboxylase; neither isomer of mandelate was present in the selection medium.

Mutants expressing phenylglyoxylate decarboxylase constitutively were isolated on the basis of ability to grow on phenylglyoxylate in the presence of the anti-inducer 2-phenylpropionate (Fewson et al., 1978). The screening procedure (see Methods) introduced to eliminate strains that were not constitutive but could grow in the presence of 2-phenylpropionate as a result of some other, unidentified, mutation proved successful. Twenty-three putative mutants (derived from strains $\mathrm{C} 1041, \mathrm{C} 1040, \mathrm{C} 48$ and $\mathrm{C} 4248$ ) all proved to have a constitutive phenylglyoxylate decarboxylase. Conversely, none of a random selection of 36 strains able to grow in the presence of 2-phenylpropionate but also capable of ready growth on benzyl alcohol synthesized the enzyme constitutively. This reciprocal expression of phenylglyoxylate decarboxylase and of 
Table 1. Induction and repression of $\mathrm{D}(-)-$ and $\mathrm{L}(+)$-mandelate dehydrogenases and phenylglyoxylate decarboxylase in A. calcoaceticus mutant strains C1041 and C4248

The mutants were grown in $5 \mathrm{~mm}$-L-glutamate/salts medium containing appropriate additions, which were all at $5 \mathrm{~mm}$ except for thiophenoxyacetate, which was used at $2 \mathrm{~mm}$ in the case of strain C1041. The bacteria were harvested and then enzyme activities measured in extracts as described in Methods.

\begin{tabular}{|c|c|c|c|c|c|c|}
\hline \multirow[b]{3}{*}{$\begin{array}{l}\text { Addition to } \\
\text { medium }\end{array}$} & \multicolumn{6}{|c|}{ Enzyme specific activities [nmol $\min ^{-1}(\mathrm{mg} \text { protein })^{-1}$ ] } \\
\hline & \multicolumn{3}{|c|}{ Mutant C1041 } & \multicolumn{3}{|c|}{ Mutant C4248 } \\
\hline & $\begin{array}{l}\mathrm{D}(-) \text {-Man- } \\
\text { delate dehy- } \\
\text { drogenase }\end{array}$ & $\begin{array}{c}\mathrm{L}(+)-\text { Man- } \\
\text { delate dehy- } \\
\text { drogenase }\end{array}$ & $\begin{array}{l}\text { Phenylgly- } \\
\text { oxylate de- } \\
\text { carboxylase }\end{array}$ & $\begin{array}{l}\mathrm{D}(-)-\mathrm{Man}- \\
\text { delate de- } \\
\text { hydrogenase }\end{array}$ & $\begin{array}{c}\mathbf{L}(+)-\text { Man- } \\
\text { delate de- } \\
\text { hydrogenase }\end{array}$ & $\begin{array}{l}\text { Phenylgly- } \\
\text { oxylate de- } \\
\text { carboxylase }\end{array}$ \\
\hline & 1 & 0 & 0 & 3 & 0 & 0 \\
\hline -Mandelate & 54 & 57 & 466 & 59 & 37 & 367 \\
\hline -Mandelate & 46 & 52 & 541 & 74 & 31 & 492 \\
\hline nylglyoxylate & 46 & 71 & 595 & 94 & 57 & 494 \\
\hline $\begin{array}{l}\text { ophenoxyacetate } \\
\text { nylglyoxylate } \\
\text { - 2-phenyl- }\end{array}$ & 14 & 24 & 109 & 41 & 44 & 256 \\
\hline $\begin{array}{l}\text { ropionate } \\
\text { nylglyoxylate }\end{array}$ & 0 & 0 & 0 & 2 & 3 & 0 \\
\hline succinate & 21 & 16 & 272 & 26 & 13 & 179 \\
\hline
\end{tabular}

benzyl alcohol dehydrogenase and benzaldehyde dehydrogenase II extends the previous observations of Beggs \& Fewson (1977) but is still unexplained.

The frequency of spontaneous occurrence of constitutive mutants in all the parental strains tested was about 1 in $10^{7}$. The frequency could be increased by mutagenesis (see Methods) but most of our work has been done with spontaneous mutants.

Mutants of wild-type NCIB 8250 were isolated by alternative routes (Fig. 2). In some, the ability to oxidize $\mathrm{D}(-)$-mandelate was introduced first, then second-stage mutants were selected which had a constitutive phenylglyoxylate decarboxylase (e.g. strains $\mathrm{C} 1123$ and $\mathrm{C1219}$ ). In others, mutants were first made constitutive for the original mandelate enzymes and then second-stage mutants were isolated that could grow on $\mathrm{D}(-)$-mandelate (e.g. C1006).

Measurements of enzyme activities were made on several mutants with constitutive phenylglyoxylate decarboxylase activity: twelve (e.g. C1219) had been derived from C1041, three (e.g. C4654) from C48; five (e.g. C1123) from C1040, four (e.g. C1006) from C1005 and three (e.g. C4664) from C4248. In all cases the evolved dehydrogenases, as well as the original mandelate enzymes, were synthesized constitutively. Representative results are listed in Table 2 along with results for the parental strains. None of the constitutive strains grown on L-glutamate without inducer oxidized benzoate or possessed any detectable catechol-1,2-oxygenase activity (results not shown). The inducible strains NCIB 8250, C1408, C1041, C1040, C48 and C4248 had no detectable activities of any of the enzymes listed in Table 2 unless they had been grown in the presence of phenylglyoxylate (results not shown); after induction, they contained not only the enzymes necessary to form benzoate (Table 2) but they could also oxidize benzoate [100 to $450 \mathrm{nmol} \mathrm{O}_{2} \min ^{-1}$ (mg protein) ${ }^{-1}$ ] and possessed catechol-1,2-oxygenase activity [100 to 200 $\mathrm{nmol} \min ^{-1}$ (mg protein $)^{-1}$.

\section{Conclusions}

There are two types of evidence that the regulation of the enzymes converting $D(-)$ mandelate into benzoate in wild-type strain EBF 65/65 is extremely similar to the regulation of the enzymes converting $L(+)$-mandelate into benzoate in wild-type strain NCIB 8250. First, in mutants such as $\mathrm{C} 4248$ phenylglyoxylate, thiophenoxyacetate and 2-phenylpropionate act as inducer, gratuitous inducer and anti-inducer respectively just as they do in mutants such as C1041 or in NCIB 8250 itself (Table 1; Livingstone \& Fewson, 1972; Fewson et al., 1978). 
Table 2. Enzyme activities of various mutant strains of $A$. calcoaceticus

The mutants were grown in $5 \mathrm{mM}-\mathrm{L}$-glutamate/salts medium with or without $5 \mathrm{~mm}$-phenylglyoxylate.

The bacteria were harvested and the enzyme activities measured as described in Methods.

\begin{tabular}{|c|c|c|c|c|c|}
\hline \multirow[b]{2}{*}{ Strain } & \multirow[b]{2}{*}{ Addition } & \multicolumn{4}{|c|}{ Enzyme specific activities [ $\mathrm{nmol} \mathrm{min}^{-1}(\mathrm{mg} \text { protein })^{-1}$ ] } \\
\hline & & $\begin{array}{l}\mathrm{D}(-) \text {-Mandelate } \\
\text { dehydrogenase }\end{array}$ & $\begin{array}{l}\mathrm{L}(+) \text {-Mandelate } \\
\text { dehydrogenase }\end{array}$ & $\begin{array}{c}\text { Phenylglyoxylate } \\
\text { decarboxylase }\end{array}$ & $\begin{array}{l}\text { Benzaldehyde } \\
\text { dehydrogenase }\end{array}$ \\
\hline NCIB 8250 & Phenylglyoxylate & 0 & 93 & 614 & 14 \\
\hline $\mathrm{C} 1005$ & None & 0 & 81 & 709 & 13 \\
\hline C1408 & Phenylglyoxylate & 0 & 0 & 466 & 25 \\
\hline $\mathrm{C} 1041$ & Phenylglyoxylate & 79 & 90 & 597 & 27 \\
\hline $\mathrm{C} 1040$ & Phenylglyoxylate & 62 & 0 & 642 & 12 \\
\hline $\mathrm{C} 1006$ & None & 97 & 126 & 1012 & 10 \\
\hline $\mathrm{C} 1123$ & None & 107 & 0 & 901 & 13 \\
\hline $\mathrm{C} 1219$ & None & 61 & 71 & 761 & 22 \\
\hline $\mathrm{C} 48$ & Phenylglyoxylate & 103 & 0 & 814 & 25 \\
\hline C4654 & None & 111 & 0 & 552 & 36 \\
\hline $\mathrm{C} 4248$ & Phenylglyoxylate & 137 & 46 & 770 & 44 \\
\hline C4664 & None & 125 & 48 & 824 & 38 \\
\hline
\end{tabular}

Secondly, mutants (e.g. C4654) can be isolated that constitutively synthesize the first three enzymes of the mandelate pathway (Table 2); in this respect they resemble the equivalent mutants of NCIB 8250 such as C1005 (Table 2; Fewson et al., 1978).

The most important conclusion of the work described here is that in mutants of $A$. calcoaceticus that have gained an extra mandelate dehydrogenase, the novel enzymes are invariably regulated co-ordinately with the pre-existing mandelate enzymes (Tables 1 and 2). It was already known that all the mandelate dehydrogenases have very similar properties and in particular that the novel $\mathrm{D}(-)$-mandelate dehydrogenase of NCIB 8250 is remarkably like the original $\mathrm{D}(-)$-mandelate dehydrogenase of $\mathrm{EBF} 65 / 65$ and the novel $\mathrm{L}(+)$-mandelate dehydrogenase of $\mathrm{EBF} 65 / 65$ is equally similar to the original $\mathrm{L}(+)$-mandelate dehydrogenase of NCIB 8250 (Hills \& Fewson, 1983). Therefore if, as we have suggested (Hills \& Fewson, 1983), the new enzymes arose as a result of expression of silent genes then it would appear that these genes are intimately related to those that are expressed in the wild-type strains.

Parts of this work were supported by grants from the Medical Research Council. C. A.H. was in receipt of a Medical Research Council studentship. We are grateful for the technical assistance of Mr A. Scott.

\section{REFERENCES}

Ahlquist, E. F., Fewson, C. A., Ritchie, D. A., PoDmore, J. \& Rowell, V. (1980). Competence for genetic transformation in Acinetobacter calcoaceticus NCIB 8250. FEMS Microbiology Letters 7, 107-109.

BEGGS, J. D. \& FEwson, C. A. (1977). Regulation of synthesis of benzyl alcohol dehydrogenase in Acinetobacter calcoaceticus NCIB 8250. Journal of General Microbiology 103, 127-140.

Beggs, J. D., Cook, A. M. \& Fewson, C. A. (1976). Regulation of growth of Acinetobacter calcoaceticus NCIB 8250 on benzyl alcohol in batch culture. Journal of General Microbiology 96, 365-374.

Fewson, C. A., Livingstone, A. \& Moyes, H. M. (1978). Mutants of Acinetobacter calcoaceticus NCIB 8250 constitutive for the mandelate enzymes. Journal of General Microbiology 106, 233-239.

Hakvey, N. L., Fewson, C. A. \& Holms, W. H. (1968). Apparatus for batch culture of micro-organisms. Laboratory Practice 17, 1134-1136.
Hegeman, G. D. (1966). Synthesis of the enzymes of the mandelate pathway by Pseudomonas putida. I. Synthesis of enzymes by the wild type. Journal of Bacteriology 91, 1140-1154.

Hills, C. A. \& Fewson, C. A. (1979). Regulation of mandelate dehydrogenases with altered stereospecificity in mutant strains of Acinetobacter calcoaceticus. Society for General Microbiology Quarterly 6, 96.

Hills, C. A. \& Fewson, C. A. (1983). Mutant strains of Acinetobacter calcoaceticus possessing additional mandelate dehydrogenases. Identification and preliminary characterization of the enzymes. Biochemical Journal 209, 379-386.

Livingstone, A. \& Fewson, C. A. (1972). Regulation of the enzymes converting L-mandelate into benzoate in bacterium NCIB 8250 . Biochemical Journal 130, 937-946.

Livingstone, A., Fewson, C. A., Kennedy, S. I. T. \& Zatman, L. J. (1972). Two benzaldehyde dehydro- 
genases in bacterium NCIB 8250. Distinguishing properties and regulation. Biochemical Journal 130, 927-935.

REINER, A. M. (1971). Metabolism of benzoic acid by bacteria: 3,5-cyclohexadiene-1,2-diol-1-carboxylic acid is an intermediate in the formation of catechol. Journal of Bacteriology 108, 89-94.

Stanier, R. Y. \& Ornston, L. N. (1973). The $\beta$ - ketoadipate pathway. Advances in Microbial Physio$\log y$ 9, 89-151

Towner, K. J. (1978). Chromosome mapping in Acinetobacter calcoaceticus. Journal of General Microbiology 104, 175-180.

TOWNER, K. J. \& Vivian, A. (1976). RP4-mediated conjugation in Acinetobacter calcoaceticus. Journal of General Microbiology 93, 355-360. 